
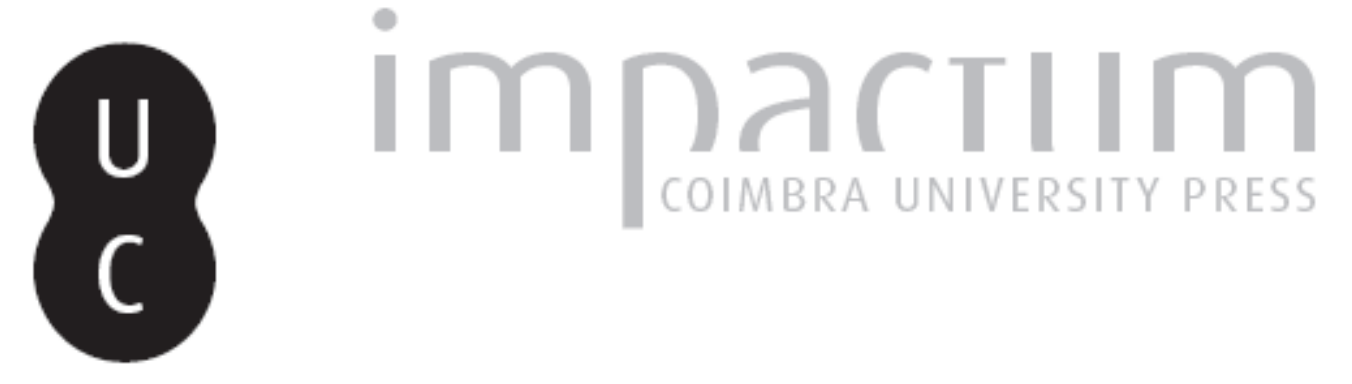

\title{
A baixa de Coimbra em finais da Idade Média: sociedade e cotidiano nas freguesias de S. Bartolomeu e Santiago
}

Autor(es): $\quad$ Augusto, Octávio Cunha Gonçalves Simões

Publicado por: Centro de História da Sociedade e da Cultura

URL persistente:

URI:http://hdl.handle.net/10316.2/39387

DOI:

DOI:http://dx.doi.org/10.14195/1645-2259_13_5

Accessed : $\quad$ 26-Apr-2023 10:52:39

A navegação consulta e descarregamento dos títulos inseridos nas Bibliotecas Digitais UC Digitalis, UC Pombalina e UC Impactum, pressupõem a aceitação plena e sem reservas dos Termos e Condições de Uso destas Bibliotecas Digitais, disponíveis em https://digitalis.uc.pt/pt-pt/termos.

Conforme exposto nos referidos Termos e Condições de Uso, o descarregamento de títulos de acesso restrito requer uma licença válida de autorização devendo o utilizador aceder ao(s) documento(s) a partir de um endereço de IP da instituição detentora da supramencionada licença.

Ao utilizador é apenas permitido o descarregamento para uso pessoal, pelo que o emprego do(s) título(s) descarregado(s) para outro fim, designadamente comercial, carece de autorização do respetivo autor ou editor da obra.

Na medida em que todas as obras da UC Digitalis se encontram protegidas pelo Código do Direito de Autor e Direitos Conexos e demais legislação aplicável, toda a cópia, parcial ou total, deste documento, nos casos em que é legalmente admitida, deverá conter ou fazer-se acompanhar por este aviso.

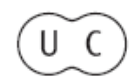



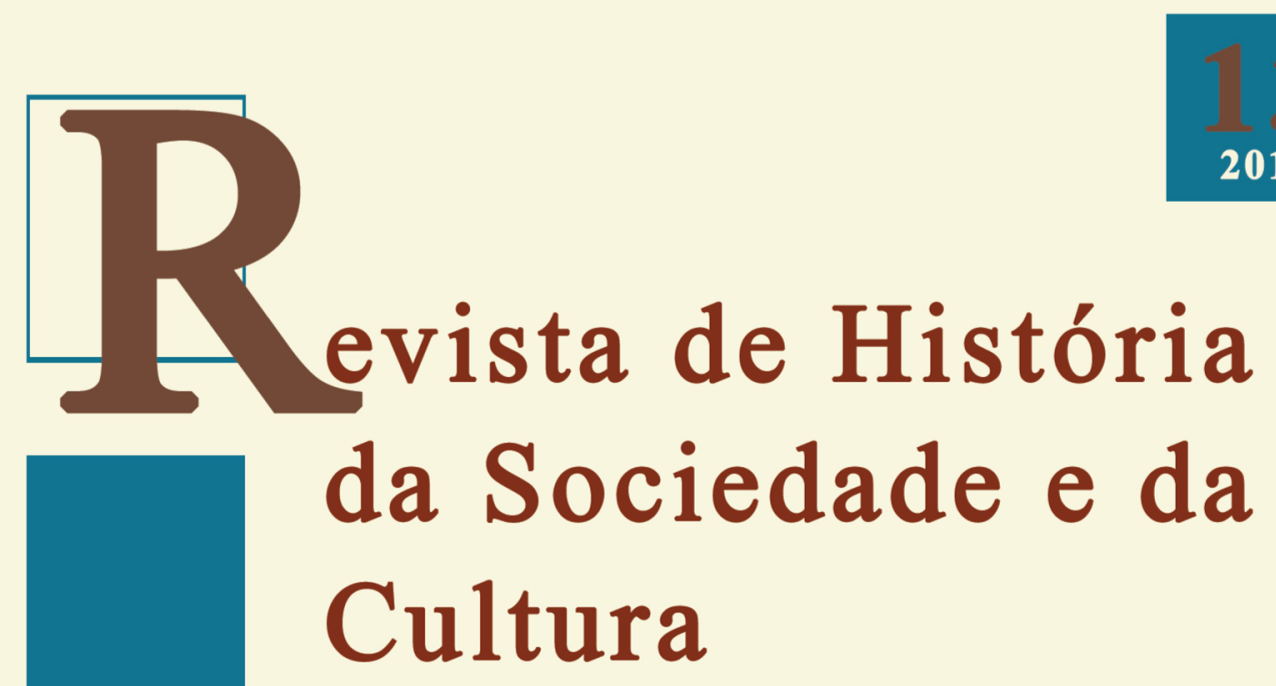

2013

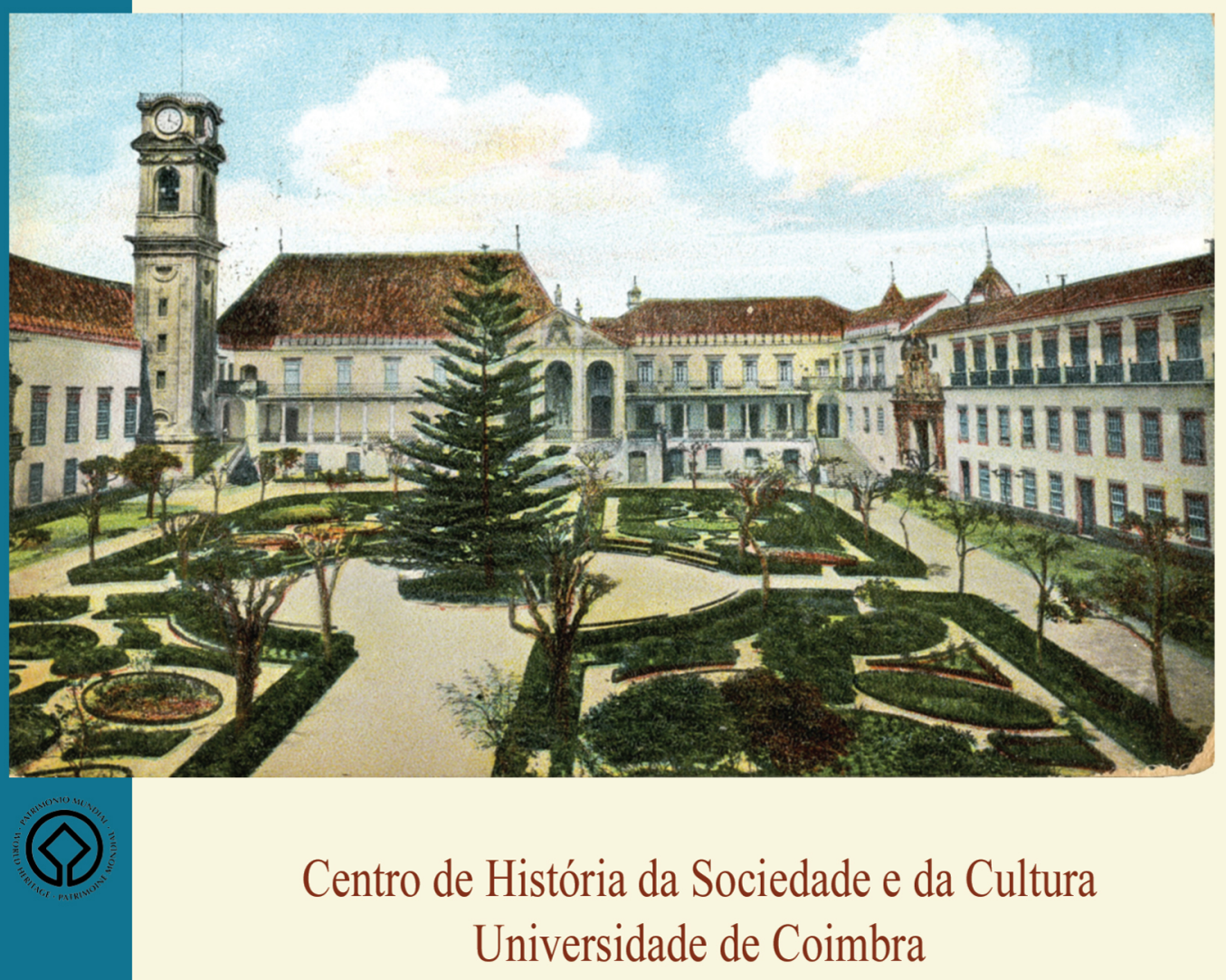

Coimbra 


\title{
A Baixa de Coimbra em finais da Idade Média: Sociedade e cotidiano nas freguesias de S. Bartolomeu e Santiago
}

\author{
Octávio Cunha Gonçalves Simões Augusto \\ Mestre em História Medieval pela Faculdade de Letras da Universidade de Coimbra \\ Colaborador do Centro de História da Sociedade e da Cultura \\ octavio_cgsa@hotmail.com \\ Texto recebido em /Text submitted on: 06/05/2013 \\ Texto aprovado em / Text approved on: 10/08/2013
}

\section{Resumo/Abstract:}

O objetivo principal do presente trabalho é proceder a uma abordagem da sociedade e do cotidiano das freguesias medievais de S. Bartolomeu e Santiago, situadas na Baixa de Coimbra, tendo como base um dos capítulos da nossa tese de mestrado. Através de um percurso pelas ruas que compunham tal área, procuramos identificar as atividades económicas que mais se desenvolviam no local, assim como as personagens que ali habitavam, tentando recriar alguns aspectos do cotidiano vivido neste espaço do arrabalde durante a Idade Média. A concretização dos objetivos enunciados foi possível através do cruzamento de diferentes fontes de informação, de entre as quais destacam-se a manuscrita e a cartográfica, que permitiram-nos a recolha de dados e descrições importantes para o entendimento do cotidiano e do contexto socioeconómico.

The main objective of this work is to make an approach on society and daily life of medieval parishes of St. Bartholomew and St. James, located in downtown Coimbra, based on one of the chapters of our master thesis. Looking through the streets that composed this area, we sought to identify the economic activities that developed over the place, as well as the characters who lived there, trying to recreate some aspects of everyday life in this area of the suburbs during the Middle Ages. The achievement of the objectives listed above was made possible through the crossing of different sources of information, specially handwritten and cartographic sources, whereby we collected data and descriptions valuable to the understanding of everyday life and socioeconomic context of downtown Coimbra in the medieval period.

Palavras chave/Keywords:

Coimbra; Sociedade; Cotidiano; S. Bartolomeu; Santiago.

Coimbra; Society; Daily life; S. Bartolomeu; Santiago. 


\section{Introdução}

Em nossa recentemente concluída tese de mestrado $^{1}$, debruçamo-nos sobre os aspectos urbanísticos e socioeconómicos de uma área específica de Coimbra medieval, situada nos arrabaldes - ou seja, no tecido urbano existente fora do perímetro muralhado - e então englobada pela freguesia de S. Bartolomeu e pela extinta freguesia de Santiago, localizadas nas margens do Mondego. Nosso objetivo foi elucidar, através da análise de fontes de natureza variada, as origens da Praça da cidade - atualmente designada de Praça do Comércio - e que ali encontrava-se situada.

Como pudemos averiguar em nossas pesquisas, este espaço urbano surge em finais do séc. XIV - tendo sido documentado pela primeira vez em 1395 - e terá tomado forma, ao que tudo indica, a partir da transferência da feira franca para fora de muralhas, em 1391, passando a realizar-se no local onde atualmente se encontra a Praça ${ }^{2}$. Complementado o processo, o subsequente esforço concelhio de dotar o local de importantes equipamentos urbanos acabará por elevá-la a posição de novo centro cívico e social da cidade, característica plenamente consolidada nos inícios da modernidade ${ }^{3}$.

1 AUGUSTO, Octávio - A Praça de Coimbra e a afirmação da Baixa: origens, evolução urbanística e caracterização social. Coimbra: dissertação de mestrado em História Medieval apresentada à Faculdade de Letras da Universidade de Coimbra, 2012.

2 Ao que tudo indica, durante a Idade Média, tanto em Coimbra como em outras cidades do reino, o vocábulo "praça" terá servido, inicialmente, para designar o espaço onde se realizavam atividades comerciais. Para uma análise aprofundada desta relação, veja-se TRINDADE, Luísa - Urbanismo na composição de Portugal. Coimbra: tese de doutoramento em História da Arte apresentada à Faculdade de Letras da Universidade de Coimbra, 2010, p. 705-719 (edição publicada pela Imprensa da Universidade de Coimbra, 2013, p. 584-595).

3 Será a partir de fins do séc. XIV que começam a aparecer na documentação notícias acerca da instalação - na área circundante à Praça - dos açougues (1398), do pelourinho (1419) e das obras de um novo paço do concelho (1437), que, ao que tudo indica, nunca terá sido concluído. Nos inícios do séc. XVI, instalam-se ali, também, o Hospital Real (1504) e reconstroem-se os açougues, permitindo que, pelo menos desde 1532, a Câmara Municipal se estabeleça definitivamente no topo deste novo edifício. AUGUSTO, Octávio - A Praça de Coimbra e a afirmação da Baixa..., cit., p. 122-139. Acerca das características estruturais e funcionais das praças medievais portuguesas, veja-se também ANDRADE, Amélia e ROSSA, Walter (ed.) - La plaza portuguesa: acerca de una continuidad de estructuras y funciones in La plaza en España e Iberoamérica: El escenario de la ciudad. Madrid: Museo Municipal de Madrid, 1998, p. 99-109. 
Este foco da municipalidade coimbrã no Arrabalde - e especialmente na área próxima ao Mondego - resulta, por sua vez, de um outro importante processo, este mais gradual e desfasado no tempo: o da própria transferência da centralidade da área intramuros para fora de muralhas.

Elevada a sede da corte durante os primeiros séculos do reino, Coimbra viveria seu auge durante o período de reconquista, quando, dada a sua estratégica posição em relação à então fronteira entre o território cristão e o muçulmano, se estabelece como importante centro político, económico e militar. Em razão das vicissitudes e incertezas de uma época de intensa atividade bélica, era, naturalmente, a área intramuros - denominada Almedina - que se afigurava como núcleo central da cidade, servindo de polo comercial e reduto da aristocracia e do clero.

$\mathrm{O}$ reinado de D. Afonso III, no entanto, anunciaria o ponto de viragem desta tradicional dinâmica socioeconómica coimbrã. A partir da vontade do monarca, a corte mudar-se-á para Lisboa, elevando-se esta a centro urbano mais importante do reino, posição que, durante algum tempo, dividiu com Santarém. Paralelamente, a tomada de Faro, em 1249, concluía o processo de reconquista, garantindo a posse de toda a região do Algarve e dando início a um longo período de paz no reino. Como consequência, as cidades ganham novo vigor e, paulatinamente, se desmilitarizam, sendo suas estruturas defensivas sufocadas pelos casarios envolventes e, por vezes, apropriadas por particulares. Finalmente, retomam-se as rotas mercantis, o comércio floresce e a economia começa a expandir-se $\mathrm{s}^{4}$.

A Almedina, neste contexto, perde prestígio. Com o abandono da corte - juntamente com seu séquito - e o consequente despovoamento da Alcáçova, a área intramuros perderá população e apresentará sintomas de relativa decadência, o que, a partir deste ponto, exigirá esforços vários por parte da Coroa - traduzidos, maioritariamente, em concessões e prerrogativas - na tentativa de atenuar a situação. Estas iniciar-se-ão logo com D. Afonso III, que concederá inúmeros privilégios fiscais àqueles que habitarem continuadamente dentro da cerca. Neste âmbito de ação destacam-se, também, a transferência do Estudo Geral para Coimbra, em 1308, efetuada

${ }^{4}$ MATTOSO, José - Mutações in MATTOSO, José (ed.) - História de Portugal. Lisboa: Editorial Estampa, 1997, vol. II, p. 210-212. 
por D. Dinis ${ }^{5}$, e as significativas concessões outorgadas aos habitantes desta zona por D. Fernando durante a década de 70 do séc. XIV ${ }^{6}$.

Os efeitos, porém, não se farão sentir de forma relevante, e a Almedina desempenhará, pelo restante da Idade Média, um penoso papel coadjuvante no contexto da cidade. Isto porque, com o abandono da corte e a consequente perda de importância da área intramuros, a centralidade acabará por deslocar-se, descendo o morro em que a cidade se desenvolve, trespassando o arco da Almedina e se consolidando, finalmente, na Baixa da cidade.

No período final da reconquista, o Arrabalde já se afigurava como um polo de comércio e produção de alguma relevância ${ }^{7}$, concentrado, sobretudo, na zona junto ao rio Mondego, área já relativamente urbanizada e que contava com a presença das importantes igrejas paroquiais de Santa Justa, Santiago e São Bartolomeu, e de antigos mosteiros. O papel desta zona, no entanto, era ainda meramente acessório, e seria somente com a perda de dinamismo na Almedina que alcançaria o protagonismo do qual gozou durante todo período tardo-medieval ${ }^{8}$.

5 Acerca desta primeira transferência da Universidade para Coimbra, veja-se COELHO, Maria Helena da Cruz - Coimbra Trecentista: A cidade e o Estudo. Biblos - Revista da Faculdade de Letras da Universidade de Coimbra. 68 (1992) 335-356, e, para documentação relacionada com o seu funcionamento, veja-se VELOSO, Maria Teresa Nobre - Livro Verde da Universidade de Coimbra: transcrição. Coimbra: Arquivo da Universidade de Coimbra, 1992.

6 Como exemplo, podemos citar os assentos de 1370, Janeiro, 25, Santarém (Instituto Arquivos Nacionais/Torre do Tombo (Lisboa) (IAN/TT) - Chancelaria de D. Fernando I Livro 1, fl. 50) e 1372, Outubro, 5, Buarcos (IAN/TT - Chancelaria de D. Fernando I - Livro 1, fl. 113 v.), que resumem-se a privilégios de ordem diversa, destacando-se os de ordem fiscal. Para uma análise mais profunda destas concessões veja-se AUGUSTO, Octávio A Praça de Coimbra e a afirmação da Baixa..., cit., p. 20-28.

7 É importante ressaltar que o comércio e a produção, sobretudo artesanal, constituíam as duas atividades com maior preponderância para o desenvolvimento da cidade medieval. LE GOFF, Jacques - O apogeu da cidade medieval. São Paulo: Martins Fontes, 1992, p. 62.

8 Convém reter que o surgimento, a partir de finais da Idade Média, de um novo foco de centralidade fora de muralhas encontra-se documentado em outras cidades do reino. Um exemplo é o caso de Lisboa, com a proeminência gradual adquirida pela zona da Ribeira. ROSSA, Walter-DiverCidade: Urbanografia do espaço de Coimbra até ao estabelecimento definitivo da Universidade. Coimbra: tese de doutoramento em Arquitetura apresentada à Faculdade de Ciências e Tecnologia da Universidade de Coimbra, 2001, p. 571-572. Também no Porto verificou-se, nos séculos XIV e XV, uma crescente afirmação económica e social da zona ribeirinha, em detrimento da zona alta, representada pelo morro da Sé. RIBEIRO, Maria do Carmo e MELO, Arnaldo Sousa - Influência das atividades económicas na organização da cidade medieval portuguesa in RIBEIRO, Maria do Carmo e MELO, 
Desta maneira, e auxiliada também pela sua privilegiada situação geográfica face aos principais acessos à cidade, a Baixa converte-se, finalmente, no principal centro de produção e, principalmente, de comércio da urbe, servindo de terreno fértil e florescendo juntamente com a burguesia mercantil, grupo social então em franca ascensão. Em conformidade com este ambiente de prosperidade e vigor económico, a área torna-se foco principal das ações da municipalidade, o que contribuirá para o aparecimento, a partir de finais do séc. XIV, de novos elementos urbanísticos no local, como é o caso da Calçada, importante via calcetada de ligação entre a Portagem e a Porta da Almedina, documentada pela primeira vez em 1392, e a já referida Praça, juntamente com os equipamentos públicos que viriam a rodeá-la.

A partir desta pequena contextualização e aproveitando-nos de um dos capítulos de nossa tese de mestrado ${ }^{9}$, exploremos mais profundamente o perfil socioeconómico das freguesias arrabaldinas de S. Bartolomeu e Santiago durante a Idade Média. Procuraremos expor, a partir de dados colhidos em documentação publicada e manuscrita, o cotidiano de quem habitava o local, identificando os principais personagens e as atividades económicas que dominariam a paisagem desta zona de extramuros, focando-nos, especialmente, nos últimos séculos da Idade Média, para os quais a informação é-nos mais abundante. Assim, seguindo uma rota pelas principais ruas e bairros das ditas freguesias - representadas no mapa a seguir -, reconstituamos as possíveis cenas e visões presenciadas por quem, no período medieval, vagueasse pela área ${ }^{10}$.

Arnaldo Sousa (eds.) - Evolução da paisagem urbana: sociedade e economia. Braga: CITCEM, 2012, p. 159.

9 "Caracterização social" in AUGUSTO, Octávio - A Praça de Coimbra e a afirmação da Baixa..., cit., p. 140-156.

${ }^{10}$ Convém reter que, muito embora a judiaria medieval situada nas imediações da Rua Corpo de Deus estivesse, na Idade Média, dentro dos limites da freguesia de Santiago, não incluímos em nossa análise a comunidade judaica ali residente, em razão de suas características peculiares, merecedoras de um estudo a parte. Para tal, veja-se, de GOMES, Saul António - A comunidade judaica de Coimbra medieval. Coimbra: Inatel, 2003, e, do mesmo autor, Ser-se judeu na Coimbra medieval in Minorias étnicas e religiosas em Portugal: história e actividade: Actas do Curso de Inverno. Coimbra: 2003, p. 61-82. 


\section{Coimbra Medieval: Ruas e equipamentos urbanos}

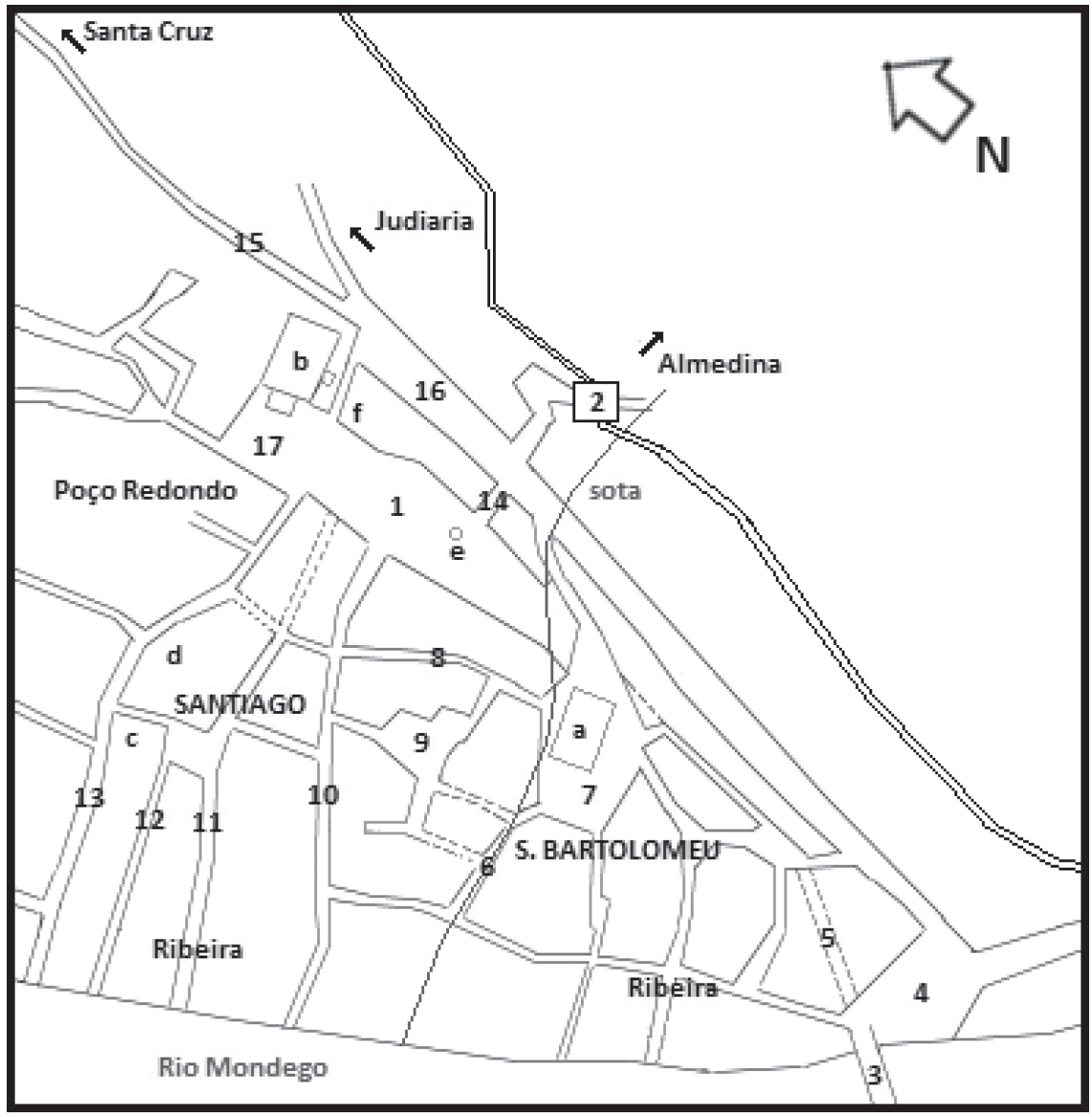

Legenda: 1 - Praça, 2 - Porta da Almedina e traçado aproximado da muralha,

3 - Ponte Afonsina sobre o Mondego, 4 - Largo da Portagem, 5 - Traçado presumido da

Rua da Ponte, 6 - Rua da Sota, 7 - Adro de S. Bartolomeu, 8 - Rua dos Prazeres,

9 - Romal, 10 - Rua de S. Gião, 11 - Possível Rua dos Peliteiros, 12 - Rua Olho do

Lobo, 13 - Rua dos Tanoeiros, 14 - Escada, 15 - Rua de Coruche, 16 - Calçada

(Rua dos Francos), 17 - Adro de Santiago. a - Igreja de S. Bartolomeu, b - Igreja de Santiago, c - Hospital de Santa Maria de S. Bartolomeu, d - Casas do prior do Hospital e Marechal do Rei, e - Pelourinho, f-Açougues ${ }^{11}$.

${ }^{11}$ Mapa adaptado do presente em AUGUSTO, Octávio - A Praça de Coimbra e a afirmação da Baixa..., Anexo I, p. 170-176, elaborado a partir do Mappa Thopografico Da Cidade de Coimbra Com a Divizão Das Antigas Freguezias (finais do século XVIII), Instituto Geográfico Português, Inv. n. ${ }^{\circ}$ CA 391. 


\section{Freguesias de S. Bartolomeu e Santiago: sociedade e cotidiano}

Quem chegava a Coimbra, vindo do sul, era obrigado a traspassar a sólida ponte de pedra sobre o Mondego, obra dos tempos de D. Afonso Henriques ${ }^{12}$ e que se constituía como a principal via de travessia do rio. Ainda na sua margem esquerda, uma observação descomprometida já permitiria a um viajante reconhecer a organização da cidade.

No cume do morro, de desenho imponente, estaria a alcáçova, com o castelo a sua direita e, mais abaixo, uma grande muralha, dotada de altas torres, contornaria a elevação sobre a qual a cidade se erguia, separando a parte alta da parte baixa, esta situada na margem do rio, ladeada por um branco areal. À medida que se atravessava a ponte, um observador mais atento talvez reconhecesse, por entre o casario da Baixa, constituído em sua maioria por casas sobradadas ${ }^{13}$, o topo da igreja de São Bartolomeu, cujo edifício medieval tinha a fachada orientada para sudoeste.

Transpondo a porta da torre na qual a ponte afonsina culminava, chegava-se à Portagem, situada no local onde se encontra o largo homónimo. Ali, exceto em época de feira franca, era necessário pagar por quaisquer mercadorias que se trouxesse de fora da cidade. Em 1422, acompanhando este processo de pesagem e avaliação dos produtos poderia estar João Gonçalves. Tinha sido criado e porteiro "do muito honrrado dom Gil de boa memoria"14, e residia na Rua de Coruche - atual Rua Visconde da Luz -

${ }^{12}$ Apesar de a Chronica Gothorum referir a construção da ponte do rio Mondego por ordem de Afonso Henriques, em 1132, ainda que se tratasse de uma ponte nova, não há grande dúvida sobre a existência de uma anterior ponte romana em Coimbra. ALARCÃO, Jorge de - Coimbra. A Montagem do Cenário Urbano. Coimbra: Imprensa da Universidade de Coimbra, 2008, p. 145. Para mais informações acerca das pontes que atravessaram o Mondego, veja-se, do mesmo autor, As Pontes de Coimbra que se afogaram no rio. Coimbra: Ordem dos Engenheiros, 2012.

${ }^{13}$ A casa sobradada aparece, indiscutivelmente, como a tipologia mais comumente referida na documentação consultada. Para mais detalhes acerca da habitação corrente nos finais da Idade Média, veja-se TRINDADE, Luísa - A casa corrente em Coimbra: Dos finais da Idade Média aos inícios da Época Moderna. Coimbra: Câmara Municipal de Coimbra, 2002, e a coletânea de artigos de CONDE, Manuel Sílvio Alves - Construir, habitar: A casa medieval. Braga: CITCEM, 2011.

${ }^{14} \mathrm{O}$ bispo D. Gil Alma foi primeiro bispo do Porto, sendo depois transferido para Coimbra, onde já estava em 1407. Parece ter falecido em 1415. ALMEIDA, Fortunato de História da Igreja em Portugal. Porto-Lisboa: ed. Damião Peres, 1967-1971, vol. I, p. 502. 
território da antiga freguesia medieval de Santiago, com sua mulher, Maria Gil. Trabalhava, naquele momento, como portageiro, já que, juntamente com outros parceiros, tinha arrendado a portagem da cidade. O negócio, embora certamente rentável, causar-lhe-ia, no entanto, alguns problemas.

Como sabemos através das fontes, seu ofício obrigava-o a viver na arrecadação desta, onde morava durante a maior parte da semana, com exceção do domingo. Estando este edifício dentro dos limites da igreja de S. Bartolomeu, os seus cónegos fizeram uso deste argumento para lhe cobrar dízimas, contrariando o desejo do próprio João Gonçalves. Afinal, como é alegado na documentação, era em sua casa na Rua de Coruche que, juntamente com sua esposa, tinha todos os seus bens móveis, seu celeiro e adega, e onde guardavam seus animais; e era na igreja de Santiago, onde escutavam as missas, ouviam o canto litúrgico e participavam das festas. Como verdadeiros fregueses dela, era a esta que, justamente, queriam dar seu dízimo.

A contenda gerou um processo judicial de foro eclesiástico, que resultaria em uma sentença a favor de Santiago e de João Gonçalves ${ }^{15}$. Foi certamente um alívio para o portageiro saber que poderia retribuir devidamente a quem, com aparente atenção, lhe dava apoio espiritual e participava ativamente do seu dia-dia. Para Santiago, porém, seria mais um dos seus inúmeros conflitos com a paróquia vizinha, fruto de um antagonismo que parecia existir já há algum tempo entre estas ricas e prestigiadas colegiadas ${ }^{16}$. Prova disso é uma outra contenda, esta de 1349, por motivo do direito à dízima de Domingos Eanes, carpinteiro.

15 1422, Outubro, 15, Coimbra (IAN/TT - Colegiada de Santiago de Coimbra, cx. 1, m. $\left.1, \mathrm{n}^{\mathrm{o}} 178 / 71\right)$.

${ }^{16}$ Ambas estavam entre as mais ricas da cidade, ficando somente atrás da colegiada de Santa Justa, como fica provado na taxação das igrejas, de 1320. Na ocasião, Santiago contribuiu com 650 libras e S. Bartolomeu com 540, ALMEIDA, Fortunato de História da Igreja em Portugal, cit., vol. IV, p. 122. Ordem idêntica se verifica, também, na ocasião em que o bispo de Coimbra D. Jorge estabelece o quantitativo com que as colegiadas contribuiriam para as obras da cidade, Arquivo Municipal de Coimbra (AMC) Pergaminhos avulsos $n^{\circ}$ 8, publicado em MADAHIL, A. G. Rocha-Pergaminhos do Arquivo Municipal de Coimbra. Arquivo Coimbrão. 7 (1943) 300-302. Para uma análise detalhada acerca da Colegiada de S. Bartolomeu durante a Idade Média, veja-se GUARDADO, Maria Cristina Gonçalves - A colegiada de S. Bartolomeu de Coimbra em tempos medievais (das origens ao inicio do séc. XV). Coimbra: dissertação de mestrado em História Medieval, apresentada à Faculdade de Letras da Universidade de Coimbra, 1999. 
Na ocasião, este trazia emprazada uma almuinha do Mosteiro de Lorvão, situada "além da ponte", logo, fora dos limites de qualquer paróquia da cidade $^{17}$. Domingos Eanes era freguês de Santiago e, um dia, juntamente com o dizimeiro desta, media o milho para determinar a quantidade que lhe devia entregar quando, subitamente, foram abordados por homens de S. Bartolomeu que, sem explicações, lhes tomaram a dízima violentamente. O incidente gerou, também, uma sentença judicial, decidida a favor de Santiago e sustentada na evocação, por parte do juiz, do longínquo costume local de, caso a herdade não ser de outra igreja nem estar dentro dos limites de alguma paróquia, a dízima dever ser paga à colegiada de que se é freguês ${ }^{18}$.

De volta à Portagem, após o pagamento dos devidos direitos, um viajante recém-chegado à cidade certamente optaria, ou seria recomendado, a seguir em direção às freguesias de $\mathrm{S}$. Bartolomeu e Santiago. Em um decreto de D. Fernando, datado de 1377, o rei acatava um pedido do concelho - decerto dando continuidade a um costume já existente - de que as estalagens se localizassem na área destas duas paróquias ${ }^{19}$.

Uma rota possível em direção ao centro destas freguesias seria pela Ribeira - denominação medieval da área beira-rio situada na margem esquerda do Mondego - ladeando o famoso Arnado ${ }^{20}$. Uma visão inevitável para quem por ali passasse seria a dos barcos ali estacionados. Sabemos, por exemplo, que na segunda metade do séc. XIV, os barqueiros Estácio Martins ${ }^{21}$ e André Vicente tinham propriedades nas proximidades, assim

${ }^{17}$ O termo "além da ponte", na Idade Média, referia-se a margem esquerda do Mondego. Assim nos evidencia um documento onde este mesmo termo é utilizado para localizar uma almuinha que confrontava, a oriente, com o Arnado e com a ponte. 1240, Junho (IAN/TT Colegiada de S. Cristóvão de Coimbra, cx. 9, m. 2, n 22). Encontra-se publicado, assim como todos os documentos provenientes desta colegiada utilizados neste trabalho, em MATOS, João da Cunha - A Colegiada de S. Cristóvão de Coimbra (sécs. XII e XIII). Tomar: trabalho apresentado ao concurso de provas públicas para Professor Coordenador, 1998, vol. II.

${ }^{18}$ 1349, Setembro, 15, Coimbra (IAN/TT - Col. Santiago, cx. 1, m. 5, nº 60).

19 "...outorgamos que as stalageens sejam no aravalde a parte de Sam Bertolameu e de Santiago" - 1377, Agosto, 12, Lisboa (IAN/TT - Chancelaria de D. Fernando I, Livro 2, fl. 11 v.).

${ }^{20}$ Era assim designado o areal (arenatum) que marginava o rio Mondego. "Arnado" ainda hoje serve de designação a uma zona junto ao rio situada dentro da atual freguesia de Santa Cruz, nos arredores da Rua da Sofia.

${ }^{21}$ 1378, Abril, 23, Coimbra (IAN/TT - Colegiada de S. Bartolomeu de Coimbra, cx. 2, m. $\left.6, \mathrm{n}^{\mathrm{o}} 17\right)$. Encontra-se publicado, assim como todos os documentos provenientes desta 
como, provavelmente, o pescador Vasco Paiola ${ }^{22}$. André Vicente, especificamente, recebera de emprazamento um cortinhal na Ribeira ao qual Lourenço Martins, "Desbarbado" de alcunha, tinha renunciado. "Nom podia manter $o$ dicto cortinhal porque era ja homem velho e pobre", alegava ${ }^{23}$.

Também próximo ao rio Mondego, abundariam os estabelecimentos mecânicos. Em toda zona da Ribeira e na Rua da Ponte ${ }^{24}$, temos notícia da existência de lagares de azeite, pelames e alcaçarias, algumas destas últimas pertencentes à confraria dos Sapateiros ${ }^{25}$. Trabalhos duros e sujos, por vezes exalando cheiros incómodos, estariam situados junto ao Mondego não somente dada a necessidade ocasional do uso da água como força motriz, assim como pela facilidade de escoamento das impurezas geradas por tais atividades. Isto, conjugado com a proximidade à sota - canal de esgoto que atravessava a Ribeira de S. Bartolomeu, rumo ao rio, correndo provavelmente em vala aberta - e a natural imundície das ruas medievais resultaria, certamente, em um local desagradável e insalubre.

Tal situação, porém, não impedia que figuras de diversas camadas da população habitassem e fossem proprietários na região limítrofe ao rio. Sabemos que, próximo de uns lagares de azeite na Rua da Ponte, estavam as casas de Afonso Peres, porteiro do bispo ${ }^{26}$. Confrontando com uma estrutura não identificada designada de Pedernedo, situada nesta via, estavam as casas de João de Alpoim $^{27}$ e, na Rua da Sota, morou Vasco Martins, porteiro do

colegiada utilizados neste artigo, em GUARDADO, Maria Cristina Gonçalves - A colegiada de S. Bartolomeu de Coimbra em tempos medievais..., cit., Vol. II.

22 1397, Março, 5, Coimbra (IAN/TT - Col. S. Bartolomeu cx. 3, m. 7, nº 7).

23 1386, Outubro, 22, Coimbra (IAN/TT - Col. S. Bartolomeu cx. 2, m. 6, no 28).

${ }^{24}$ Em nossa dissertação de mestrado, avançamos a hipótese de tal rua atravessar o atual espaço constituído pelo Largo da Portagem, desenvolvendo-se em linha com o traçado da ponte medieval e culminando na Travessa dos Gatos. AUGUSTO, Octávio A Praça de Coimbra e a afirmação da Baixa..., cit., p. 46-49.

25 1308, Março, 8, Coimbra (IAN/TT - Col. S. Bartolomeu, cx. 6, m. 14, no 5). Para maiores detalhes acerca das confrarias medievais portuguesas, veja-se COELHO, Maria Helena da Cruz - As confrarias medievais portuguesas: espaços de solidariedades na vida e na morte in Cofradias, gremios, solidariedades en la Europa Medieval, Estella: XIX Semana de Estudios Medievales, 1992, p. 149-183, e GOMES, Saul António - Notas e documentos sobre as confrarias portuguesas entre o fim da Idade Média e o século XVII: O protagonismo dominicano de Sta. Maria da Vitória. Lusitania Sacra. $2^{a}$ série, 7 (1995) 89-150.

${ }^{26} 1346$ Junho, 13, Coimbra (IAN/TT - Col. S. Bartolomeu, cx. 6, m. 14, nº 13).

27 1381, Janeiro, 20, Coimbra (IAN/TT - Col. S. Bartolomeu, cx. 2, m. 6, nº 21). João de Alpoim era casado com Maria Domingues, filha de Domingos Antoninho (1389, Janeiro, 12, 
concelho $^{28}$. Por fim, Martim Domingues, senhor do Hospital de Ceira ${ }^{29}$, e Vasco Garcia, escudeiro, também detinham ali propriedades ${ }^{30}$.

A Rua da Sota, segundo a hipótese que avançámos em nossa dissertação de mestrado, corresponderia, na Idade Média, à atual Rua dos Esteireiros e, portanto, desembocaria no adro da igreja de S. Bartolomeu ${ }^{31}$. Centro nevrálgico da freguesia, aqui também encontrar-se-iam, caminhando por entre as campas que rodeavam o templo, entrando e saindo da igreja, ou simplesmente à porta de suas casas, indivíduos de extratos sociais diversificados. Em finais do séc. XII, temos notícia que ali teria propriedades o moedeiro e alvazil D. Telo ${ }^{32}$, enquanto que, para o século XIV, chegam-nos testemunhos de clérigos ali residentes, como Gonçalo Peres, prior de Ceira e raçoeiro de S. Bartolomeu ${ }^{33}$, assim como homens do rei, caso de Estácio Anes $^{34}$ e Diogo Peres ${ }^{35}$.

Porém, a maioria dos que habitavam nas imediações do adro parecem ser mesteirais, com a presença de alguns mercadores. Sobre os primeiros,

Coimbra (IAN/TT - Col. S. Bartolomeu, cx. 2, m. 6, no 31), e provavelmente teria algum parentesco com Geraldo de Alpoim, raçoeiro de S. Bartolomeu em 1369 (1369, Junho, 19, Coimbra (IAN/TT - Col. S. Bartolomeu, cx. 2, m. 6, nº 2b). Sabemos, também, que seriam seus criados Pedro Afonso (1375-1405, Novembro, 30 - Dezembro, 1, Coimbra (IAN/ /TT - Col. S. Bartolomeu, cx. 3, m. 7, n 12) e Gonçalo Lourenço, casado com Maria Gil (1396, Novembro, 21, Coimbra, IAN/TT - Col. S. Bartolomeu, cx. 3, m. 7, nº 6). Podemos ainda identificá-lo com o João de Alpoim que aparece nomeado, em 1390, como juiz do rei D. João I (RIBEIRO, João Pedro - Dissertações chronologicas e criticas sobre a historia e jurisprudência ecclesiastica e civil de Portugal. Lisboa: Academia Real das Sciencias de Lisboa, 1836, Tomo V, p. 139), e que ainda atuava como sobrejuiz durante o reinado de D. Duarte (FREITAS, Judite A. Gonçalves - O Portugal Atlântico e o Portugal Mediterrâneo na itinerância régia de meados do século XV (1433-1460) in Estudos em Homenagem ao Professor Doutor José Marques. Porto: Faculdade de Letras da Universidade do Porto, 2006, vol. I, p. 503). Por fim, poderá estar relacionado com Lopo de Alpoim, que em 1468 aparece como membro do concelho municipal (1468, Fevereiro, 7, Coimbra (AMC - Pergaminhos avulsos $\left.\mathrm{n}^{\circ} 86\right)$.

${ }^{28}$ 1391, Fevereiro, 10-20, Coimbra (IAN/TT - Col. S. Bartolomeu, cx. 2, m. 5, no 36).

${ }^{29}$ Filho de Salvador Domingues e casado com Senhorinha Martins. (1391, Fevereiro, 10-20, Coimbra (IAN/TT - Col. S. Bartolomeu, cx. 2, m. 5, nº 36).

${ }^{30}$ 1409, Setembro, 8, Coimbra (IAN/TT - Col. S. Bartolomeu, cx. 2, m. 6, nº 20).

${ }^{31}$ Para a fundamentação de tal proposta, veja-se AUGUSTO, Octávio - A Praça de Coimbra e a afirmação da Baixa..., cit., p. 49-50, 58-60, 66-67.

${ }^{32}$ 1192, Maio, publicado em GOMES, Saul António - Entre memória e história: os primeiros tempos da Abadia de Santa Maria de Alcobaça (1152-1215). Revista de História da Sociedade e da Cultura. 2 (2002) doc. 18.

33 1391, Abril, 8, Coimbra (IAN/TT - Col. S. Bartolomeu, cx. 3, m. 7, n 2).

${ }^{34}$ 1369, Junho, 19, Coimbra (IAN/TT - Col. S. Bartolomeu, cx. 2, m. 6, no 2b).

35 1396, Novembro, 21, Coimbra (IAN/TT - Col. S. Bartolomeu, cx. 3, m. 7, nº 6). 
as fontes falam-nos, para os séculos XIV e XV, sobretudo, em sapateiros, alfaiates e carpinteiros. Encontramos também uma oleira, Maria Peres, que deixou em testamento, à colegiada de $\mathrm{S}$. Bartolomeu, as casas em que morava, situadas no local. Teria criado junto de si uma rapariga, de nome Catarina Carnes, a quem recompensou, juntamente com uma tal Constança, com uma casa em Cabo de Cavaleiros, "com esta condiçom que a dicta Costança ensigne a tecer a dicta Cathelina Carnes" ${ }^{36}$. Por fim, fazendo jus a determinação outorgada por D. Fernando décadas antes, convém citar Gonçalo Seco, "estalageiro", presente como testemunha, em finais de trezentos, em dois atos celebrados na igreja de S. Bartolomeu, indício de que talvez seu estabelecimento ficasse por perto ${ }^{37}$.

Para quem decidisse rumar a norte, uma opção seria uma estreita rua que nascia no adro, em frente à porta lateral do templo, e que seguia para a freguesia de Santiago. Era a Rua dos Prazeres, atualmente denominada de beco $^{38}$, e que na Idade Média seria uma longa via pela qual também se tinha acesso ao atual Largo do Romal - então um terreiro de proporções desconhecidas - os dois espaços formando, nos séculos XIV e XV, uma espécie de bairro eclesiástico ${ }^{39}$. É o que as fontes nos dão a entender, já que são abundantes, para estas datas, os testemunhos sobre clérigos na posse de casas nesta área, pertencentes, na maioria das vezes, ao cabido da igreja de São Bartolomeu.

Era o caso de João Gomes, raçoeiro ${ }^{40}$; João Domingues, capelão ${ }^{41}$; Vasco Peres, prioste ${ }^{42}$, e dois priores, Sancho Garcia e Raimundo Beltrães ${ }^{43}$. Acerca

${ }^{36}$ 1370, Outubro, 7 (IAN/TT - Col. S. Bartolomeu, cx. 2, m. 6, nº 3).

37 1392, Dezembro, 4, Coimbra (IAN/TT - Col. S. Bartolomeu, cx. 3, m. 7, no 4) e 1396, Novembro 21, Coimbra (IAN/TT - Col. S. Bartolomeu, cx. 3, m. 7, nº 6).

${ }^{38}$ Tal topónimo encontra-se documentado desde 1368, sendo, porém, desconhecida sua origem. 1368 Janeiro, 22, Coimbra (IAN/TT - Col. S. Bartolomeu cx. 2, m. 5, nº 36).

${ }^{39}$ Para uma análise das feições medievais do Largo do Romal e da Rua dos Prazeres, veja-se AUGUSTO, Octávio - A Praça de Coimbra e a afirmação da Baixa ..., cit., p. 60-65.

40 1375, Julho, 2, Coimbra (IAN/TT - Col. S. Bartolomeu, cx. 2, m. 6, nº 9).

${ }^{41}$ 1375, Julho, 2, Coimbra (IAN/TT - Col. S. Bartolomeu, cx. 2, m. 6, no 9).

42 1386, Junho, 3, Coimbra (IAN/TT - Col. S. Bartolomeu, cx. 2, m. 6, n⿳⺈ 26-27).

${ }^{43}$ Ambos figuram no instrumento de 1391, Maio, 26, Coimbra (IAN/TT - Col. S. Bartolomeu, cx. 3, m. 7, no 3). Sancho Garcia foi prior entre, pelo menos, 1348 e 1366, enquanto Raimundo Beltrães aparece exercendo o cargo entre 1369 e 1412 . GUARDADO, Maria Cristina Gonçalves, A colegiada de S. Bartolomeu de Coimbra em tempos medievais..., cit., p. 172-173. 
deste último, algum tempo após sua morte surge nas fontes, executando seu testamento, o seu filho Diogo Beltrães ${ }^{44}$, fruto de um relacionamento do prior com sua "servente", Maria Anes ${ }^{45}$, e aparentemente um dos muitos exemplos de filhos resultantes do concubinato no seio do clero português medieval.

Era vulgar na Idade Média que padres vivessem, temporária ou permanentemente, com amantes, pelo que a aparição de Diogo Beltrães em uma série de documentos lidando com os assuntos do pai é indício desta relativa normalidade ${ }^{46}$. O problema de sua ilegitimidade, por sua vez, foi resolvido logo em 1400, quando teve seu nascimento legalizado por meio de uma carta de legitimação de D. João I ${ }^{47}$ e, em 1416, ao decidir que se manteria na posse, entre outras propriedades, de uma casa na Rua dos Prazeres, até invocando o fato de a decisão ter sido tomada após um aparentemente custoso acordo entre seus irmãos, "por partirem dentre si grandes ódios e malquerenças e grandes custas e despesas que se sobr'ello podiam segir e segia e pera ficarem amigos", indicando, assim, que talvez não fosse o único fruto da relação. Neste mesmo documento, aparece como raçoeiro de S. Cristóvão, o que comprova-nos, definitivamente, que seguira os passos do pai $^{48}$.

Sua mãe, porém, não teve o mesmo tratamento condescendente por parte dos clérigos de S. Bartolomeu. Não parece ter sido excomungada nem presa, como as leis da época o exigiam, mas, após a morte de Raimundo Beltrães, continuou a utilizar um cortinhal que este tinha de emprazamento, situado no Romal. A situação duraria pouco, e os cónegos logo reclamariam a devolução da propriedade, conseguida após processo judicial, muito embora

${ }^{44}$ 1412, Julho 4, Coimbra (IAN/TT - Col. S. Bartolomeu, cx. 3, m. 7, nº 24a).

${ }^{45}$ No documento, Maria Anes é referida como "servent (sic) que foy de Reymom Beltraeez”. [1412, Fevereiro 25-1415, Maio 22], Coimbra (IAN/TT - Col. S. Bartolomeu, cx. $\left.6, \mathrm{~m} .14, \mathrm{n}^{\mathrm{o}} 23\right)$.

${ }^{46}$ Como nos informa A. H. de Oliveira Marques, só durante o período de 1398 a 1438 contam-se mais de 700 legitimações de filhos oriundos de "clérigos barrigueiros", sendo a prática do concubinato, a despeito das punições legais previstas para os religiosos infratores, largamente presente desde os mais baixos aos mais altos cargos da hierarquia eclesiástica, MARQUES, A. H. de Oliveira - A Sociedade Medieval Portuguesa: aspectos de vida quotidiana. Lisboa: A Esfera dos Livros, $6^{\mathrm{a}}$ edição, 2010, p. 157-159.

${ }^{47}$ 1400, Março, 11, Santarém (IAN/TT - Chancelaria de D. João I, Livro 3, fl. 112 v.). Esta chancelaria encontra-se publicada em Chancelarias portuguesas: D. João I. Lisboa: Centro de Estudos Históricos da Universidade Nova de Lisboa, 2004.

${ }^{48}$ 1416, Maio 21, Coimbra (IAN/TT - Col. S. Bartolomeu, cx. 3, m. 7, nº 34a). 
seja mencionado que Maria Anes estaria disposta a apelar para Braga ${ }^{49}$. Não sabemos se tal recurso terá surtido algum efeito ${ }^{50}$.

Ainda acerca do Romal, sabemos que, para além de clérigos, na centúria de trezentos eram proprietários nos seus entornos, também, alfaiates, uma padeira e até mesmo tabeliães, caso de Martim Bravo $^{51}$ e Vasco Afonso ${ }^{52}$, bem como o escudeiro Diogo Álvares e João Esteves, escrivão dos contos do rei ${ }^{53}$.

Ao atravessar o terreiro que constituía o Romal, chegar-se-ia então à Rua de S. Gião, onde a visão mais comum seria, certamente, a de ânforas e tonéis, manuseados e transportados por almocreves como Bartolomeu Martins, ali proprietário ${ }^{54}$. Com efeito, mesmo ainda sem a designação atual de Rua das Azeiteiras, nela podemos identificar, segundo documentação dos séculos XIV e XV, uma primitiva concentração de lagares de azeite, produto que, em finais de trezentos, constituía a principal riqueza de Coimbra ${ }^{55}$. Fernando Afonso, lavrador, e sua esposa, Margarida Domingues, até escambam, em 1375, duas geiras de terra nos campos do Mondego por uma antiga casa térrea - chamada "Estrebaria da Rainha" - naquela via, com a intenção de nela montar um estabelecimento deste tipo ${ }^{56}$.

A própria freguesia de S. Bartolomeu, no seu todo, parece ter sido, no período medieval, uma área de grande importância na produção deste

49 [1412, Fevereiro 25-1415, Maio 22], Coimbra (IAN/TT - Col. S. Bartolomeu, cx. 6, m. 14, no 23).

${ }^{50}$ Ainda acerca da mancebia, temos notícia, também, de Maria Gonçalves, que aparece referenciada, em documento de 1348, como manceba de um cónego de S. Bartolomeu, cujo nome não se encontra legível no documento. 1348, Dezembro, 28, Coimbra (IAN/TT - Col. S. Bartolomeu, cx. 2, m. 5, n 19).

${ }^{51}$ 1353, Novembro, 20, Coimbra (Arquivo da Universidade de Coimbra (AUC) Pergaminhos do Cabido da Sé, Dep. V, $3^{\text {a }}$ sec., mov. 1, gav. 2, $n^{\circ}$ 68). Martim Bravo parece ter ocupado, também, a posição de almoxarife, como nos revela um documento acerca de uma transação em qual estava envolvida a sua viúva, Maria Domingues - 1363, Fevereiro, 11, Coimbra (IAN/TT - Col. Santiago, cx. 1, m. 3, no 608/634).

${ }_{52}$ 1377, Julho, 7, Coimbra (IAN/TT - Col. S. Bartolomeu cx. 2, m. 6, nº 15).

${ }^{53}$ Respectivamente: 1391, Fevereiro, 10-20, Coimbra (IAN/TT - Col. S. Bartolomeu, cx. 2, m. 6, n 36), e 1400, Janeiro, 10, Coimbra (IAN/TT - Col. S. Bartolomeu cx. 3, m. 7, $\left.\mathrm{n}^{\mathrm{o}} 10\right)$.

${ }^{54}$ 1374, Janeiro, 25, Coimbra (IAN/TT - Col. S. Bartolomeu cx. 2, m. 6, no 5).

${ }_{55}$ COELHO, Maria Helena da Cruz - Homens e negócios in COELHO, Maria Helena da Cruz, Ócio e Negócio. Coimbra: Inatel, 1998, p. 140.

${ }^{56}$ 1375, Outubro, 14, Coimbra (IAN/TT - Col. S. Bartolomeu, cx. 2, m. 6, no 11). 
óleo, dada a quantidade de lagareiros que aparecem na documentação ${ }^{57}$, estando tais estabelecimentos, por vezes, na posse de membros ilustres da sociedade. Caso notório é o do nobre Fernando Fernandes Cogominho. Em 1258, juntamente com sua mulher, Joana Dias, e as irmãs desta, Teresa e Mor Dias, vendeu a D. Boa Peres, mãe das ditas donas, os quinhões que possuíam nuns lagares de azeite, situados na dita freguesia ${ }^{58}$, que lhes terão ficado, a elas, de herança após a morte do pai, Vicente Dias ${ }^{59}$.

Confrontando com estes lagares a sul, estava um terreno que havia pertencido a Martim Anes de Aveiro, justamente o mais antigo tabelião público de Coimbra de que se tem notícia, tendo sua existência sido documentada desde pelo menos $1199^{60}$, e como ocupante daquele cargo desde $1219^{61}$. A história deste tabelião confunde-se, também, com a da própria freguesia, já que ao falecer, em $1227^{62}$, foi sepultado na igreja de S. Bartolomeu, deixando-lhe bens e nela instituindo uma capela ${ }^{63}$.

${ }^{57}$ A título de exemplo, podemos citar uma sentença que obrigou seis lagareiros da freguesia de $\mathrm{S}$. Bartolomeu a pagar a dízima do azeite e da baganha à igreja de $\mathrm{S}$. Bartolomeu. 1335, Maio, 13 (IAN/TT - Col. S. Bartolomeu, cx. 6, m. 14, nº 9).

${ }_{58}$ 1258, Fevereiro, transcrito em SANTOS, Ana Paula Figueira - A fundação do Mosteiro de Santa Clara de Coimbra (da instituição por D. Mor Dias à intervenção da Rainha Santa Isabel). Coimbra: dissertação de mestrado em História Medieval apresentada à Faculdade de Letras da Universidade de Coimbra, 2000, doc. 2.

${ }^{59} \mathrm{D}$. Mor Dias, à época, encontrava-se recolhida no Mosteiro de S. João das Donas e, em 1283, obteria licença para fundar o Mosteiro de Santa Clara, situado na margem esquerda do Mondego. Sobre o assunto, veja-se SANTOS, Ana Paula Figueira - A fundação do Mosteiro de Santa Clara de Coimbra ..., cit.. Sua mãe, D. Boa Peres, era neta do chanceler Julião Pais, enquanto seu marido, D. Vicente Dias, foi advogado de Coimbra e sobrejuiz de Afonso III. VENTURA, Leontina - A Nobreza de Corte de Afonso III. Coimbra: tese de doutoramento em História da Idade Média apresentada a Faculdade de Letras da Universidade de Coimbra, 1992, vol. II, p. 654-657.

${ }^{60} 1199$ (IAN/TT - Col. S. Cristóvão, cx. 9, m. I, no 22).

${ }^{61}$ RAMOS, Cláudia Maria Novais Toriz da Silva - O Mosteiro e a Colegiada de Guimarães (ca. 950-1250). Porto: dissertação de mestrado em História Medieval apresentada a Faculdade de Letras da Universidade do Porto, 1991, vol. II, doc. 262.

${ }^{62}$ DAVID, Pierre e SOARES, Torquato de Sousa (ed.) - Liber Anniversariorum Ecclesie Cathedralis Colimbriensis (Livro das Kalendas). Coimbra: Faculdade de Letras da Universidade de Coimbra, 1947-48, t. II, p. 109.

${ }^{63} \mathrm{Na}$ visitação feita à igreja de S. Bartolomeu por João Garcia Manrique, arcebispo de Santiago e administrador do bispado de Coimbra, diz-se: "achamos na dicta eglesia hũa capella a qual estabeleceu Martin d'Aveiro na dicta egreja pera a qual leixou certos beens e fez benfeytorias". [1402-1406], Coimbra (IAN/TT - Col. S. Bartolomeu, cx. 1, m. 3, $\mathrm{n}^{\mathrm{o}} 3$ ). 
Ainda na Rua de S. Gião, confrontando de um dos lados com a dita "Estrebaria da Rainha", estava um cortinhal pertencente a Constança Esteves. Era então viúva do almoxarife Afonso $\mathrm{Anes}^{64}$, e ambos tinham sido proprietários de umas casas e de outro cortinhal nesta mesma rua, doados, em 1363, à igreja de Santiago, de onde eram fregueses ${ }^{65}$. Em 1397, certamente em idade avançada, redigiu seu testamento, onde expressa o desejo de ser enterrada nesta igreja junto ao marido, já aí sepultado, com a particularidade de, no primeiro dia após sua morte, ser velada na Sé - de onde então era freguesa - já que as casas em que morava eram "pequenas e estreytas"66.

Não sabemos se a viúva se terá mudado para a paróquia sede após a morte do marido, ou se seria dali originária. É perceptível, no entanto, a relação afetiva com o Arrabalde, local que certamente habitou e onde, segundo indicam as fontes, ainda teria o que lhe restava da família, já que não encontramos em seu testamento indícios de que tivesse filhos ou netos vivos. Assim sendo, Constança Esteves faz questão de deixar cem libras a Catarina Esteves, uma de suas sobrinhas, casada com João Gil, alfaiate, a quem encontramos, em documento de 1373, em posse de casas a par da igreja de $\mathrm{S}$. Bartolomeu, onde possivelmente residiam ${ }^{67}$. A viúva também não esqueceria o sobrinho-neto, João, filho do casal, a quem deixa outras cem libras com destino louvável: "pera liuros E pera quem ho emsynarem (sic)".

À época em que se redigiu o testamento, Constança Esteves vivia na companhia de uma tal Senhorinha, a quem acabou por deixar um olival "alem da ponte na Varzea e quatro geiras de terra no campo de Mondego", estipulando que, à morte desta, tais propriedades fossem transferidas para a Albergaria de Santa Maria de São Bartolomeu, cuja sede se situava

\footnotetext{
${ }^{64}$ Afonso Anes, além de almoxarife, atuou também como mercador e vereador de Coimbra, chegando a ser preso por dívidas do almoxarifado. COELHO, Maria Helena da Cruz - Homens e negócios, cit., p. 138.

${ }^{65}$ 1363, Janeiro, 13, Coimbra (IAN/TT - Col. Santiago, cx. 1, m. 1, nº 286/100).

${ }_{66}^{6}$ 1397, Fevereiro, 26 (AUC - Tombo velho do Hospital Real, Dep. IV, $2^{\text {a }}$ E, Tab. 5, $\mathrm{n}^{\circ} 1$, fls. 2 v.-6) publicado em GOMES, Saul António - Notas e documentos sobre as confrarias portuguesas..., cit., doc. 3 .

${ }^{67}$ 1373, Maio, 1, Coimbra (IAN/TT - Col. S. Bartolomeu, cx. 2, m. 6, nº 4). Estas confrontam com casas de Vasco Afonso, tabelião, referido em outro documento como antigo possuidor de casas no Romal, indício que talvez ali se localizasse as casas de João Gil. 1377, Julho, 7, Coimbra (IAN/TT - Col. S. Bartolomeu, cx. 2, m. 6, nº 15).
} 
na freguesia de Santiago ${ }^{68}$. Ao lado do edifício onde estava instalada a albergaria, encontravam-se as casas que, no séc. XVI, seriam reformadas para servir de Paços do Conde de Cantanhede, e que correspondem, por certo, às doadas por D. João I, em 1390, ao prior do Hospital e Marechal do Rei, Álvaro Gonçalves Camelo ${ }^{69}$.

Junto da casa que pertenceu a esta personagem, na Idade Média, corriam três ruas: a Rua dos Tanoeiros, atual Adelino Veiga; a Rua Olho do Lobo, atual Rua das Rãs e, provavelmente, a Rua dos Peliteiros, sendo as três paralelas e culminando no Arnado $^{70}$. Como os próprios topónimos nos indicam, por ali estariam concentrados, em finais da Idade Média, os tanoeiros, fabricantes de tonéis - destinados ao armazenamento de diversos produtos, dentre os quais, certamente, o azeite produzido na freguesia vizinha - e os peliteiros, curtidores de peles, especializados na obtenção da pelica, couro fino, de uso nobre ${ }^{71}$.

${ }^{68}$ Tal albergaria e hospital, fundados em 1343 e extintos com a criação do Hospital Real, estavam localizados entre a atual Adelino Veiga e o Beco do Mendonça. Cf. AUGUSTO, Octávio - A Praça de Coimbra e a afirmação da Baixa..., cit., p. 71-72 e SARAIVA, Anísio Miguel de Sousa - A propriedade urbana das confrarias e hospitais de Coimbra nos finais da Idade Média. Revista de Ciências Históricas. Universidade Portucalense. 10 (1995) 160.

${ }^{69}$ As casas encontram-se descritas, no Tombo Velho do Hospital Real, como as "cassas que fforam do marichall E ora ssam do comde de cantanhede". Veja-se GOMES, Saul António - Notas e documentos sobre as confrarias portuguesas..., cit., doc. 3 e nota 10. Álvaro Gonçalves Camelo, que era prior do Crato desde 1384, sucede nas funções de marechal da hoste de D. João I, em 1386, a Álvaro Gonçalves Pereira. Era-o, ainda, em 11 de Setembro de 1396 (CORREIA, Francisco Carvalho - O Mosteiro de Santo Tirso, de 978 a 1588, Santo Tirso: Câmara Municipal de Santo Tirso, 2009, p. 268-269, doc. 164). A relação entre tal prior e a coroa seria extremamente conturbada, gerando uma tentativa de exílio em Castela - que lhe valeria a prisão em Évora e depois em Coimbra, de onde se evadiria - e uma bem-sucedida fuga para o reino vizinho, pela qual seria perdoado por D. João I. Não sabemos se terá regressado novamente a terras portuguesas. MORENO, Humberto Baquero - Contestação e oposição da nobreza portuguesa ao poder político nos finais da Idade Média. Revista da Faculdade de Letras da Universidade do Porto. $2^{\mathrm{a}}$ série, 4 (1987) 111-112.

${ }^{70}$ As justificações para as correspondências da Rua dos Tanoeiros e da Rua Olho do Lobo às atuais Rua Adelino Veiga e Rua das Rãs encontra-se em AUGUSTO, Octávio A Praça de Coimbra e a afirmação da Baixa ..., cit., respectivamente, p. 73-77, 51-53. Acerca da Rua dos Peliteiros, sua localização exata ainda é desconhecida, muito embora tenhamos avançado a hipótese desta consistir em uma versão mais extensa da atual Rua do Poço, em AUGUSTO, Octávio - A Praça de Coimbra e a afirmação da Baixa ..., cit., p. 109-122.

${ }^{71}$ Assim como no caso dos lagares, as atividades relacionadas à curtição de pele situavam-se próximas ao rio em razão da poluição por elas acarretada. No caso do Porto, Arnaldo de Sousa Melo informa-nos que os curtumes, embora concentrados na zona alta, situavam-se 
Desta forma, não é surpreendente o fato de termos encontrado nas fontes testemunhos abundantes à presença destes profissionais na área, acompanhados de mercadores e, sobretudo, de sapateiros - que certamente se utilizavam do couro ali produzido - e carpinteiros, que poderiam estar envolvidos no fabrico dos tonéis. Para a Rua dos Tanoeiros, convém destacar também que, na primeira metade do séc. XV, era ali proprietário - entre tanoeiros, sapateiros e carniceiros - o tabelião João Rodrigues ${ }^{72}$, que fora criado do infante Dom Pedro, tendo sido por pedido deste ao concelho que acedera ao tabelionato, por volta de $1429^{73}$.

A Rua dos Peliteiros, sobretudo, havia de ser uma artéria importante. O seu período áureo parece ter sido o século XIII e inícios do século XIV, centúria em que encontramos algumas referências a personalidades ilustres que nela, e em suas cercanias, detinham propriedades. Enumerando-as, citemos Vasco Gil, cónego de Santiago e tabelião público, que ali morou ${ }^{74}$; D. Pascásio Godins, que foi deão de Viseu e de Coimbra ${ }^{75}$; o chantre de

próximo do Rio da Vila, ribeiro que desembocava no Douro. Cf. MELO, Arnaldo Rui Azevedo de Sousa - Trabalho e Produção em Portugal na Idade Média: O Porto (c. 1320-c. 1425). Braga, Paris: tese de doutoramento em História da Idade Média apresentada à Universidade do Minho, École des Hautes Études en Sciences Sociales, 2009, vol. I, p. 227.

72 1431, Abril, 20, Coimbra (AUC - Pergaminhos do Cabido da Sé, Dep. V, $3^{\text {a }}$ sec., mov. 1, gav. 7, $\mathrm{n}^{\circ}$ 198).

${ }^{73}$ SANTOS, Maria José Azevedo - Alguns aspectos do tabelionado em Coimbra (séculos XIV-XV). Arquivo Coimbrão. 33-34 (1993) 7, nota 11. Conseguimos atestar sua atividade como tabelião de, pelo menos, 1429 a 1435 (1429, Junho, 10, Coimbra (IAN/TT - Mosteiro de Santa Clara, m. 6, n ${ }^{\circ}$ 399); 1435, Setembro, 26, Coimbra (IAN/TT - Mosteiro de Celas, m. 12, n $\left.{ }^{\mathrm{o}} 38\right)$ ). Em relação a sua família, sabemos somente que era genro de um tal Lopo Álvares (1431, Abril, 20, Coimbra (AUC - Pergaminhos do Cabido da Sé, Dep. V, $3^{\text {a }}$ sec., mov. 1, gav. 7, $\mathrm{n}^{\circ}$ 198)). Para mais detalhes acerca do tabelionado coimbrão, veja-se GOMES, Saul António - Percepções em torno da história do tabelionado medieval português. Revista de História da Sociedade e da Cultura. 5 (2005) 81-100.

${ }^{74}$ 1267, Junho, 26 (IAN/TT - Col. Santiago, cx. 1, m. 5, nº 308).

${ }^{75}$ DAVID, Pierre David e SOARES, Torquato de Sousa (ed.) - Livro das Kalendas, cit., t. I, p. 173, informa-nos que D. Pascásio era proprietário de casas na rua dos Peliteiros, e um documento de 1245, Setembro, 28 (IAN/TT - Cabido da Sé de Coimbra, $1^{\text {a }}$ incorp., m. 14, $\mathrm{n}^{\circ}$ 7) refere-se a uma casa na Rua Olho do Lobo (por nós identificada com a Rua das Rãs) e que confrontava a leste com as deste indivíduo. D. Pascásio Godins era filho de Godinho Pais, moedeiro e alvazil da cidade, pertencente aos Godins de Coimbra. Era irmão de Teresa Godins, casada com Lourenço Gonçalves Magro, miles, amo de D. Dinis. Encontra-se sepultado, juntamente com sua irmã, no claustro da Sé de Coimbra. VENTURA, Leontina e GOMES, Saul António - Leiria na crise de 1245-1248. Documentos para uma revisão crítica. Revista Portuguesa de História. 28 (1993) 197, nota C8; GOMES, Saul António 
Viseu e cónego de Coimbra Lourenço Esteves de Formoselha ${ }^{76}$; Gonçalo Esteves, que havia sido escudeiro de D. Astrigo, raçoeiro da Sé77, e Aldonça Anes de Molnes, monja de Lorvão ${ }^{78}$. Próximo das casas habitadas por esta última, estariam outras, pertencentes ao seu irmão, o fidalgo Paio Anes de Molnes $^{79}$. Convém mencionar aqui, também, o alvazil Tomás Martins, que habitou em uma platea, na freguesia de Santiago, que poderá corresponder à Rua dos Peliteiros ${ }^{80}$.

Rumando pela Rua dos Tanoeiros em direção à igreja de Santiago, atingir-se-ia, em inícios do séc. XV, a Praça. Devia parecer, nesta época, um grande terreiro de formato ainda um tanto irregular, sendo provável que não se estendesse até ao adro de S. Bartolomeu, como nos dias atuais. A meio desta, em frente a uma pequena escada encrustada no casario, já lá estava o pelourinho e, próximo dali, imediatamente ao lado da igreja de Santiago, os açougues. Em segundo plano, imponente, a muralha e suas torres ${ }^{81}$.

- Reguengo do Fetal. Documentos Históricos. Fetal: Junta de Freguesia do Reguengo do Fetal, 2012, doc. 16, p. 45-47.

${ }^{76}$ Filho de Estevão Eanes de Formoselha, cavaleiro e vassalo da casa do infante D. Dinis, e de Sancha Afonso, sobrinha do Chanceler D. Estevão Anes. Lourenço Esteves aparece pela primeira vez na documentação em 1279, tendo vindo a morrer em Coimbra, no ano de 1318, em suas casas na Rua dos Peliteiros. Veja-se MORUJÃO, Maria do Rosário Barbosa e SARAIVA, Anísio Miguel - O chantre de Viseu e cónego de Coimbra Lourenço Esteves de Formoselha: Uma abordagem prosopográfica. Lusitania Sacra. 2a série, 13-14 (2001-2002) $75-137$.

77 1333, (?) (IAN/TT - Cabido da Sé de Coimbra, 2 a incorp., m. 77, nº 3193).

${ }^{78}$ Irmã de Paio Anes de Molnes, era monja de Lorvão em 1279 quando, autorizada pela sua abadessa, nomeou procurador o seu irmão Paio Esteves, para que se procedesse às partilhas dos bens paternos (IAN/TT - Mosteiro de Vairão, m. 4, n 32). Desconhecemos em que ano saiu de Lorvão, mas o certo é que em 1303 já seria abadessa do mosteiro de Almoster (1303, Março, 30 (IAN/TT - Cabido da Sé de Coimbra, 2a incorp., m. 88, no 4143 e 4201).

${ }^{79}$ Irmão de Aldonça Anes, dita Molnes, é documentado pela primeira vez em 1272. Casou, antes de 1276, com Maria Martins, filha de Martim Anes, copeiro de D. Afonso III, e com a qual teve nove filhos. Sua esposa falece em 1288, tendo ele casado em segundas núpcias com Beatriz Pires Pereira, com quem teve apenas um filho. Faleceu antes de 1292. Foi proprietário de diversos bens na Terra do Vouga e, sobretudo, na Terra de Faria. Cf. PIZARRO, José Augusto de Sotto Mayor-Linhagens medievais portuguesas: genealogias e estratégias, 1279-1325. Porto: Centro de Estudos de Genealogia, Heráldica e História da Família da Universidade Moderna, 1999, vol. II, p. 1011-1012.

${ }^{80}$ 1291, Julho, 25, Coimbra (IAN/TT - Col. Santiago, cx. 1, m. 1, no 545). Aparece como alvazil de Coimbra em 1265, Fevereiro, 18, Lisboa (IAN/TT - Mosteiro de Santa Cruz, m. 20, n' 27).

${ }^{81}$ Para uma análise detalhada da evolução urbanística da Praça de Coimbra durante a Idade Média, veja-se AUGUSTO, Octávio - A Praça de Coimbra e a afirmação da Baixa..., 
Nos quarteirões à volta da Praça estariam em curso, provavelmente, demolições e novas edificações, no âmbito do processo de reorganização do espaço que lhe deu a configuração atual. Das que já ali estavam, algumas seriam dotadas de alpendres, como ao que renunciou, em 1455, Afonso Martins, que fora criado do infante D. Pedro, alegando ser "homem prove (sic) e meesteirosso". Tal alpendre confrontava com casas do barbeiro Álvaro Fernandes e outras que haviam pertencido a Martim Afonso, também barbeiro e, à época, já falecido ${ }^{82}$.

A pequena concentração destes profissionais no local é entendível. Afinal, a Praça, em meados de quatrocentos, já seria um lugar relativamente central. Ademais, lembremos que os barbeiros, além de apararem a barba e o cabelo, tinham outras atribuições, dentre as quais pequenas intervenções médicas, como era o caso das sangrias. Seu local de trabalho afigurava-se, também, como um espaço de convívio masculino. No século XIV, o severo clérigo castelhano Martín Perez, por exemplo, via grande perigo no ajuntamento de homens no barbeiro, assim como, em contraponto, na concentração de mulheres nas casas de fiandeiras ${ }^{83}$.

Em dias comuns, o movimento na Praça não seria muito diferente do resto dos arruamentos. Transeuntes, tendas, algumas vendedeiras, carros de bois, crianças correndo ou pombas ciscando - alimentando-se, talvez, do que havia sido deixado da última feira semanal - seriam visões comuns. Esta relativa tranquilidade, porém, não devia equiparar-se ao bulício que a Praça experienciava em tempos de feira franca.

Durante os reinados de D. Fernando e D. João I, esta ocorria de 15 de Setembro a 15 de Outubro. Coincidia com o S. Miguel de Setembro, época de colheitas e de pagamento de rendas, e a ela acorria gente de todo o termo, para comprar e para vender, constituindo-se no verdadeiro encontro entre o campo e a cidade.

Tais características faziam da feira, portanto, um vivo e colorido retrato da sociedade medieval. Era ali que o abastado burguês citadino exibia suas

cit., p. 109-139. Acerca da praça medieval portuguesa, veja-se também TRINDADE, Luísa - Urbanismo na composição de Portugal, cit., p. 705-719.

82 1455, Março, 26 (AMC - Pergaminhos avulsos nº 74).

${ }^{83}$ MATTOSO, José - O corpo, a saúde e a doença in MATTOSO, José (ed.) - História da Vida Privada em Portugal - A Idade Média. Lisboa: Círculo de Leitores, 2010, p. 353. 
roupas adornadas e sua bolsa cheia de moedas, procurando pelo melhor sapato, o melhor tecido ou, talvez, alguma joia. Impressionava, com toda a certeza, o lavrador que, vindo de uma localidade recôndita nos confins do termo coimbrão, aproveitara as isenções fiscais próprias do evento para montar uma banca e vender o produto de suas colheitas a fim de obter algum lucro, que talvez fosse gasto por ali mesmo, em um novo utensílio doméstico ou peça de roupa para sua família. À sua banca, acorria, entre muitos outros, o mesteiral local, com o intuito de abastecer-se do que era necessário para as suas atividades e, no processo, surpreender-se ao passar por estrangeiros a balbuciarem uma língua estranha, vendendo panos exóticos ou outros produtos vindos de fora do reino. Tudo isto, claro, vigiado pelos oficiais do concelho, dispostos a manter a ordem e que tinham no pelourinho, situado bem ao centro da praça, tanto um instrumento de punição como um elemento representativo do poder municipal ${ }^{84}$.

Por fim, em frente a porta da igreja Santiago, alguns cónegos reúnem-se no alto de sua escadaria, juntamente com um casal. A meio deles, sentava-se um tabelião, rabiscando um grande livro. Era algum emprazamento a tomar forma. Foi este o caso, por exemplo, de Diogo Lourenço e Catarina Anes que, em 5 de Outubro de 1437, em plena feira, receberam de emprazamento, do Mosteiro de São Jorge, um casal e herdade em Santa Luzia, termo de Coimbra, tendo o contrato sido celebrado "ante a porta prinçipal da egreja de San Tiago" 85 .

A ocasião, porém, não seria só para negócios. Era, também, a oportunidade de rever os amigos, quem sabe fazer outros novos, atualizar-se acerca das novidades e comentar os assuntos do reino, da cidade, da família, e, até mesmo, da vida alheia. Do que falavam exatamente? Não sabemos, mas podemos supor. Muito provavelmente, um assunto corrente na feira de 1395 seria, por exemplo, o do divórcio entre Afonso Fernandes e

${ }^{84}$ Acerca da feira de Coimbra, veja-se também COELHO, Maria Helena da Cruz A feira de Coimbra no contexto das feiras medievais portuguesas in COELHO, Maria Helena da Cruz (ed.) - Ócio e Negócio, cit., p. 1-45.

${ }^{85}$ 1437, Outubro, 5, Coimbra (AUC - Mosteiro de São Jorge, Dep. V - $3^{\mathrm{a}}$ sec. mov. $\left.11-\mathrm{n}^{\circ} 59\right)$. 
Catarina Martins ${ }^{86}$. Ele, dito da Cordeirã, fora escrivão do almoxarifado ${ }^{87}$, e ela, filha de Martim Lourenço, conhecido por Malha e que sabemos ter sido almoxarife de Coimbra entre 1361 e $1367^{88}$. Foram casados por dez anos e eram, certamente, conhecidos dos moradores da zona da Praça, pois tinham uma casa na Rua dos Peliteiros e um cortinhal em Poço Redondo, localidade próxima ${ }^{89}$.

Não sabemos o que terá causado o divórcio e, muito menos, de quem teria partido a iniciativa, se de um dos cônjuges ou se, em uma hipótese menos provável, da Igreja ${ }^{90}$. Teria o ex-escrivão abandonado a esposa? Era um dos motivos que levariam a tal fim. Se assim o fosse, dar-nos-ia razões para interpretar as quinhentas libras que uma tal Catarina Beata "avia de dar ao dicto Affonso Fernandez do corregimento de pallavras que dissera do dicto Affonso Fernandez" - referidas no instrumento de partilha de bens do casal - como o possível resultado de uma pouco respeitosa observação em relação ao caso. De qualquer modo, a situação era rara e, tratando-se de personagens de alguma visibilidade, certamente terá gerado comentários.

Nesta mesma época, outro tópico que deveria estar entre os discutidos pelos habitantes da cidade seria o da insegurança durante a noite. O povo, este, já apontava culpados: os homens responsáveis pela guarda noturna. Aparentemente, o alcaide-mor, ao invés de utilizar, para este fim, funcionários conhecidos, "escriptos nos livros", valia-se do serviço de "homees vaadios

${ }^{86}$ 1395, Fevereiro, 3, Coimbra (AUC - Pergaminhos do Cabido da Sé, Dep. V, $3^{\text {a }}$ sec., mov. 1, gav. 6, $\mathrm{n}^{\mathrm{o}} 171$ ).

${ }^{87}$ Somos informados acerca de sua atividade através de um assento no registro de propriedades do almoxarifado, a respeito das suas casas na Rua dos Peliteiros, IAN/TT Núcleo Antigo, 287, Almoxarifado de Coimbra, fl. XIIII.

${ }^{88}$ Assim nos é noticiado por carta de quitação de D. João I, treslada em pública forma em 1393, Dezembro, 12 (AUC - Pergaminhos do Cabido da Sé, Dep. V, $3^{\text {a }}$ sec., mov. 1, gav. $\left.6, \mathrm{n}^{\circ} .169\right)$.

${ }^{89}$ Localizava-se imediatamente a oeste do Adro de Santiago e também servia de denominação para uma torre. AUGUSTO, Octávio - A Praça de Coimbra e a afirmação da Baixa..., cit., p. 80-86.

${ }^{90}$ Os divórcios, na Idade Média, ocorriam através da anulação do casamento e subsequente partilha de bens. As razões para seu procedimento podiam estar em um eventual abandono do cônjuge ou em um constatado caso de consanguinidade, já que a Igreja proibia qualquer enlace entre indivíduos relacionados até ao $4^{\circ}$ grau de parentesco. VENTURA, Leontina A família: o léxico in MATTOSO, José (ed.) - História da Vida Privada em Portugal A Idade Média, cit., p. 112-113. 
e nom conheçudos", não sendo incomum o aparecimento, ao raiar do sol, de pessoas maltratadas e até mesmo mortas, dentre outros malefícios. Por vezes, após a descoberta destes crimes, os ditos homens abandonavam a cidade misteriosamente, sendo "de presumir que som culpados nos dictos mallafiçios ou em parte deles". Foi este o conteúdo de uma reclamação ao rei, por ocasião das cortes de Santarém, em 1396, tendo o monarca mandado que fossem cumpridos os costumes da cidade de utilizar, para este fim, pessoas conhecidas da população ${ }^{91}$.

Imediatamente acima da Praça, ao cimo das escadas que, já no séc. XIV estariam situadas imediatamente em frente ao arco da Barbacã ${ }^{92}$, estava 0 eixo formado pela Calçada - antes Rua dos Francos - e a Rua de Coruche, um dos mais importantes da cidade ${ }^{93}$. Tais artérias serviram, durante 0 período medieval, como reduto de mercadores, fama confirmada por fontes contemporâneas, como é o caso de um decreto fernandino, datado de 1367, que garantia privilégios, especificamente, aos "mercadores moradores na Rua de Coruche e na Rua de Francos"94. Encontramo-los nas fontes desde as primeiras menções a ambas as ruas, em inícios do século XIII, tendo sido

${ }^{91}$ 1396, Maio, 9, Santarém (AMC - Pergaminhos avulsos no 46).

${ }^{92}$ As escadas em questão encontram-se documentadas desde o séc. XIV, tendo sido eliminadas no século XVI, após a construção de um chafariz na Praça. AUGUSTO, Octávio - A Praça de Coimbra e a afirmação da Baixa..., cit., p. 97.

${ }^{93}$ A Calçada e a Rua de Coruche correspondem, atualmente, à Rua Ferreira Borges e a Rua Visconde da Luz, respectivamente. Em nossa dissertação de mestrado, defendemos a hipótese da Rua dos Francos resumir-se somente ao troço situado entre a Igreja de Santiago e a Porta da Almedina, estendendo-se até à Portagem somente com o estabelecimento da Calçada, fruto de uma provável intervenção do poder local. AUGUSTO, Octávio - A Praça de Coimbra e a afirmação da Baixa..., cit., p. 87-105.

${ }^{94}$ 1367, Julho, 30, Tentúgal (IAN/TT - Chancelaria de D. Fernando I - Livro 1, fl. 118). O papel da Rua dos Francos e da Rua de Coruche como reduto de mercadores se assemelha à da Rua dos Burgueses, em Braga, e à Rua dos Mercadores, no Porto, muito embora estas últimas estivessem localizadas na zona intramuros. Cf. RIBEIRO, Maria do Carmo e MELO, Arnaldo Sousa - Influência das atividades económicas na organização da cidade medieval portuguesa, in RIBEIRO, Maria do Carmo e MELO, Arnaldo Sousa (ed.) - Evolução da paisagem urbana, cit., p. 155-156 e 163. A Calçada, via calcetada e retilínea, por sua vez, encontra paralelo nas Ruas Novas de Lisboa e Porto, tanto nas características urbanísticas como na composição social. Acerca de ambas, veja-se AMARAL, Luís Carlos e DUARTE, Luís Miguel - Os homens que pagaram a Rua Nova. Revista de História. 4 (1985) 7-96, e GONÇALVES, Iria - Uma realização urbanística medieval: o calcetamento da Rua Nova de Lisboa in GONÇALVES, Iria (ed.) - Um olhar sobre a cidade medieval. Cascais: Patrimonia Historica, 1996, p. 117-138. 
muitos deles, ao longo da Idade Média, sepultados no cercano templo de Santiago, como nos provam as diversas citações a mercadores presentes no Livro de Aniversários desta colegiada ${ }^{95}$.

Um destes afortunados comerciantes foi Estevão Domingues. Morador na Rua dos Francos e freguês de Santiago, encontramo-lo em 1347, juntamente com sua esposa Florença Fagundes, a negociar com esta igreja a sepultura de ambos, sendo noticiado, também, que a mãe desta, Joana Fernandes, já ali estava enterrada. Não deverá ter sido este, porém, o destino último deste mercador. Ao que tudo indica, foi enterrado no mosteiro de Santa Clara, já que a filha de ambos, Clara Esteves, ali terá ingressado, razão pela qual o mosteiro reclamou um terço das posses de Estevão Domingues após a sua morte. Quando este faleceu, já era casado em segundas núpcias com Iria Esteves que, como ficamos sabendo por instrumento de 1362, terá feito o inventário dos seus bens, a fim de que a subsequente partição fosse efetuada.

É com base neste inventário que temos uma noção da riqueza de um mercador coimbrão de fins de trezentos. Estevão Domingues era um negociante por excelência, já que mercava panos importados, sobretudo de lã, oriundos da Flandres e da Inglaterra. Juntamente com estes, vendia também enfeites para a confecção de vestes, como fitas, fios e botões de diversos materiais. Do seu património pessoal, destaca-se um relativo conforto e abundância de artigos de cama e mesa, incluindo-se aí almofadas, colchões, cobertores, mantas, tapetes, toalhas, vasos, taças, colheres, panelas, entre muitos outros utensílios. Também nos aparece arrolado o mobiliário da casa, constituído - entre outros objetos - por cadeiras, mesas, armários, tabuleiros e uma escrivaninha, além de diversos tipos de roupas, pertencentes tanto a Estevão Domingues como a Iria Esteves. Por fim, ficamos sabendo de suas propriedades, que se resumiam, aparentemente, a casas na Rua dos Francos e uma outra na Rua dos Tintureiros ${ }^{96}$.

${ }^{95}$ Elaborado durante os séculos XV e XVI, encontra-se publicado em sua totalidade em PEREIRA, Isaías da Rocha - Livros de aniversários de Santa Maria da Alcáçova de Santarém e de Santiago de Coimbra. Boletim da Biblioteca da Universidade de Coimbra. Coimbra Editora, 34 (1978) 6-31.

96 1362, Janeiro, 2, Coimbra (IAN/TT - Mosteiro de Santa Clara, m. 6, no 6) O que se descreve aqui é somente um resumo do dito inventário, que foi minuciosamente examinado e devidamente contextualizado por COELHO, Maria Helena da Cruz - Homens e negócios, cit., p. 127-202. 
Não era só de mercadores, no entanto, que a Rua de Coruche e a Rua dos Francos - antecessora da Calçada - eram constituídas. Desde a centúria de duzentos até meados do século XV, encontramos na documentação, além dos sempre presentes alfaiates e sapateiros, também ourives, tendeiros, cónegos, tosadores, um cutileiro, um boticário, um pintor, um barqueiro e um homem braceiro. Entre os funcionários públicos e régios, ali encontramos os tabeliães Afonso Vicente ${ }^{97}$, Miguel Lourençco ${ }^{98}$, João Afonso $^{99}$ e Pedro Afonso ${ }^{100}$; o almoxarife Pedro Juliães ${ }^{101}$, o vedor da portagem Vasco Eanes ${ }^{102}$ e o escrivão régio Domingos Anes ${ }^{103}$, o escrivão da câmara, Álvaro Gonçalves ${ }^{104}$ e Gonçalo Vasques, "esprivam (sic) que foy dos horphaãos"105. No que toca à pequena nobreza, destacamos os escudeiros João ${ }^{106}$ e João Lourenço ${ }^{107}$, além da própria Coroa que, como sabemos através das chancelarias e tombos, detinha algumas propriedades na área.

${ }^{97}$ 1347, (?), 19, Coimbra (AUC - Cópia de Emprazamentos, III- $1^{\circ} \mathrm{D}-3$, 4, 23, fl. 83, $\mathrm{n}^{\mathrm{0}} 51$ );

${ }^{9}$ 1347, Novembro, 5, Coimbra (IAN/TT - Mosteiro de São Jorge, m. 7, n 20). Neste documento, referente ao testamento de sua esposa, aparecem arroladas casas na Rua de Coruche.

${ }^{99}$ 1352, Maio, 17 (AUC - Cópia de Emprazamentos - III-1D-3, 4, 23, fl. 76 v., n 16).

${ }^{100} 1412$ Fevereiro, 25 (IAN/TT - Col. S. Bartolomeu, cx. 3, m. 7, no 23). Era casado com Constança Gonçalves, e consta que terá exercido o cargo de tabelião por incríveis 54 anos, de 1397 a 1451. Sabemos também que, pelo menos desde 1444, teria a seu serviço um escrivão, Fernando Afonso. SANTOS, Maria José Azevedo - Alguns aspectos do tabelionado em Coimbra..., cit., p. 9-10 e nota 20, p. 24.

${ }^{101}$ 1300, Março (IAN/TT - Col. Santiago). Era casado com D. Florência, e detinha a posse pardieiros situados nas traseiras de Santiago, certamente na Rua de Coruche.

${ }^{102}$ Consta que estava na posse de casas na Rua de Coruche em um assento do registro de propriedades do Almoxarifado, de 1395 (IAN/TT - Núcleo Antigo, 287, Almoxarifado de Coimbra, fl. XIIII).

${ }^{103} 1291$ (?) 12 (IAN/TT - Col. Santiago, cx. 2, m. 7, nº 316). Era então casado com uma tal D. Maria.

${ }^{104}$ 1395, Julho, 25, Sintra (IAN/TT - Chancelaria de D. João I, Livro 2, fl. 43 v.). Era proprietário de casas na Calçada. A sua viúva, Catarina Alves, aparecerá, quase meio século depois, ainda em posse das mesmas casas. 1444, Maio, 23 (AMC - Pergaminhos avulsos, $\left.\mathrm{n}^{\circ} 69\right)$.

${ }^{105}$ 1468, Fevereiro, 7 (AMC - Pergaminhos avulsos, $n^{\circ} 86$ ).

${ }^{106}$ 1389, Março, 28 (IAN/TT - Col. S. Bartolomeu, cx. 3, m. 7, no 23). O documento refere-se a um pardieiro na Rua de Coruche que, quando ainda era casa, pertencia à esposa deste, Maria Domingues.

${ }^{107} 1468$, Fevereiro, 7 (AMC - Pergaminhos avulsos, $n^{\circ}$ 86). Detinha um cortinhal na Calçada próximo da Portagem. 
Finalmente, descendo até o final desta mesma via, atingir-se-ia a Portagem, ponto de partida de nossa caminhada pelas freguesias de São Bartolomeu e Santiago de finais da Idade Média.

\section{Conclusão}

Como pudemos verificar, quem se embrenhasse pelas ruas, adros e terreiros de tais freguesias no período medieval, teria contato direto com elementos de todos os extratos sociais, e testemunharia a existência de um número relativamente diversificado de mesteres e estabelecimentos de produção.

Entre estes, merecem especial destaque os alfaiates, sapateiros e carpinteiros, presentes em toda a área, assim como os peliteiros e os tanoeiros, únicas categorias de mesteres geograficamente concentradas, instalados nas ruas que levam suas designações, na freguesia de Santiago. A freguesia de $\mathrm{S}$. Bartolomeu, por sua vez, tinha como atividade predominante a produção de azeite - como nos evidencia a alta concentração de lagares na zona próxima ao rio -, e contava, também, com a presença de alguns estabelecimentos mecânicos relacionados com a curtição de peles. Por fim, no eixo formado pela Rua de Coruche e a Calçada - antes denominada Rua dos Francos -, pela sua importância e grande extensão, encontravam-se instalados profissionais de diversas categorias e grupos sociais, entre os quais destacava-se a burguesia mercantil, que ali formava o seu reduto.

Concluindo, resta-nos reafirmar que será na Baixa que se conduzirá o desenvolvimento e se refletirá o progresso de Coimbra pelos restantes séculos do período medieval. Serão seus habitantes, homens e mulheres, mercadores e mesteres, que incrementarão o comércio e a produção, e garantirão o relevante papel da urbe no contexto do reino. Destes habitantes, tentámos obter retratos do seu cotidiano e detalhes acerca de sua identidade, revelando um pouco mais acerca destes agentes da história que, em seu conjunto, formam parte essencial do contexto socioeconómico coimbrão, no período de transição de antiga sede da corte à moderna cidade estudantil. 